\title{
Water Quantity and Quality of Six Lakes in the Arid Xinjiang Region, NW China
}

\author{
Jinglu Wu • Wen Liu • Haiao Zeng • Long Ma • \\ Ruidong Bai
}

Received: 1 November 2013 / Accepted: 18 December 2013 /Published online: 24 April 2014

(C) Springer International Publishing Switzerland 2014

\begin{abstract}
Xinjiang arid region is situated in the hinterland of Asia, characterized by very low precipitation and high evaporation. Most lakes in the region have evolved naturally to salt lakes and lagoons over the long term. In recent decades, driven by continuous climate warming and human activities, the water quantity and quality of lakes have fluctuated frequently, which has had significant impacts on regional resources and the environment. In this article, the water quantity and quality of six lakes, from saline to fresh, were studied. They are located at different geomorphologic regions (e.g., mountains and plains) in Xinjiang, China. Mountain Lakes Kanasi and Sailimu have expanded slightly, but their water quantity and quality have not changed significantly over the past decade. Oasis lakes, such as Lake Bositeng and Lake Chaiwopu, and tail-end lakes, such as Lake Wulungu and Lake Ebinur, have reduced in area, and in general, the water has become saline. Lake changes were mainly responses to the regional climate change, although factors like human activities and basin morphological characteristics have led to individual differences in lake evolution. Changes in water quality and quantity are clearly linked. Where water quantity increased, water became less salty and vice versa. Over the past decade, water quality of the mountain lakes (Sailimu and Kanasi) were relatively stable, but oasis lakes (i.e., Bositeng and Chaiwopu) continue to deteriorate, whereas water quality of the tail-end lakes (Wulungu and Ebinur) display unstable hydrochemistry.
\end{abstract}

Keywords Xinjiang arid region $\cdot$ Lake variations $\cdot$ Human activities $\cdot$ Climate change

\section{Introduction}

In arid regions, water resources are particularly vulnerable and sensitive to climate change (Piao et al. 2010; Jia et al. 2004; Micklin 1988). Lakes in arid regions are important parts of the hydrologic cycle

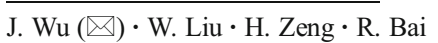

State Key Laboratory of Lake Science and Environment, Nanjing Institute of Geography and Limnology, Chinese Academy of Sciences, 73 East Beijing Road, Nanjing 210008, People's Republic of China e-mail: w.jinglu@niglas.ac.cn

L. Ma

State Key Laboratory of Desert and Oasis Ecology, Xinjiang Institute of Ecology and Geography, Chinese Academy of Sciences, Urumqi 830011, People's Republic of China 
(Leng et al. 2012; Williams 1999). Lake evolution reflects changes in water resources in the lake drainage areas, as a result of climatic changes and anthropogenic impacts (Tranvik et al. 2009; Gikas et al. 2006; Battarbee 1999; Smol 1992). In inland northwest China, the climate became warmer in the 20th century (Ding et al. 2006). From the middle to the end of the last century, the annual average temperature increased by $\sim 0.6$ to $0.8{ }^{\circ} \mathrm{C}$ (Sha et al. 2002; Zhai et al. 1999), but the annual precipitation was variable and did not show a discernible trend. Compared to the 1950s, precipitation in the Xinjiang region in the 1980s has declined (Chen et al. 1991). Following the decreases in precipitation, there was a measurable reduction in river runoff in the arid region (Lai and Ye 1995; Ren et al. 2002). Combined with human exploitation of water resources, the warm and dry climate caused many inland lakes to reduce in size or nearly completely dry, with a consequent loss of riparian swamps and forests, and desertification. In the 1970s, the Lop Nur and Lake Taitema dried completely and became saline playas (Yuan and Yuan 1998). Consequently, the Taklimakan Desert expanded eastward and united with the Kumtag Desert. Since then, there have been irreversible environmental disasters. From the late 1980s to the beginning of the 20th century, Lake Ebinur and Manasi expanded, providing a sign of climate change in the Xinjiang region (Guo et al. 2003; Shi et al. 2007). Although this finding requires confirmation, Xinjiang lakes have apparently displayed a large expansion of surface area, corresponding to the wetter climate (Ma and $\mathrm{Wu} 2009$; $\mathrm{Wu}$ and $\mathrm{Ma}$ 2011; Ma et al. 2013). Because of uncertainties about future human activities and climate changes, the fate of the lakes in the future remains unknown.

Using a survey of water quality and quantity in different types of lakes in Xinjiang, along with climate data from the drainage basins, the evolution of lakes in this arid region was studied. This study was designed to help understand the current conditions and future trends of the lakes in this arid zone. The insights it provides could also provide the scientific basis to prevent or solve current problems associated with the exploitation of the lake resources.

\section{Regional Features and Lake Distribution}

The Xinjiang Uygur Autonomous Region is situated in the northwest of the People's Republic of China. It is a vast territory with an area of $1.66 \times 10^{6} \mathrm{~km}^{2}$. It is a hinterland and is the land area most distant from the sea in the world. It is dry, receives little rainfall, and belongs to the typical temperate continental arid climate, with an average annual precipitation of only $171 \mathrm{~mm}$. From northeast to southwest, it is bounded by eight countries including Mongolia, Russia, Kazakhstan, Kyrgyzstan, Tajikistan, Afghanistan, Pakistan and India. The topography of Xinjiang can be summarized as "three mountains surrounding two basins." In the north are the Altai Mountains, in the south are the Kunlun Mountains, and in the middle are the Tianshan Mountains, which divide Xinjiang into north and south parts. Customarily, the area south of the Tianshan Mountains is called Southern Xinjiang, whereas the north part is called Northern Xinjiang. The Tarim Basin in Southern Xinjiang covers an area of $530,000 \mathrm{~km}^{2}$ and is the largest inland basin in China. The Taklimakan Desert, located in the middle of the Tarim Basin, with an area of about $330,000 \mathrm{~km}^{2}$, is China's largest and world's second largest "mobile" desert. Currently, the number of lakes with an area $>1 \mathrm{~km}^{2}$ in Xinjiang is 108 . Their total area is about $6236 \mathrm{~km}^{2}$, accounting for approximately $7.7 \%$ of the total area of the lakes in China (Ma et al. 2011). Lakes in the arid region can be classified into four types on the basis of salinity: (1) freshwater, (2) semi-saltwater, (3) salt water, and (4) dry salt. The lakes are important water resources in the region, playing an important role in the ecological integrity of the watershed and the sustainable development of the region and its economy. In this article, we report analysis of some typical lakes of the region, such as Lakes Sailimu, Ebinur, Bositeng, and Chaiwopu in the Tianshan recharge area, and Lakes Wulungu and Kanasi in the Altai Mountains recharge area (Fig. 1). 


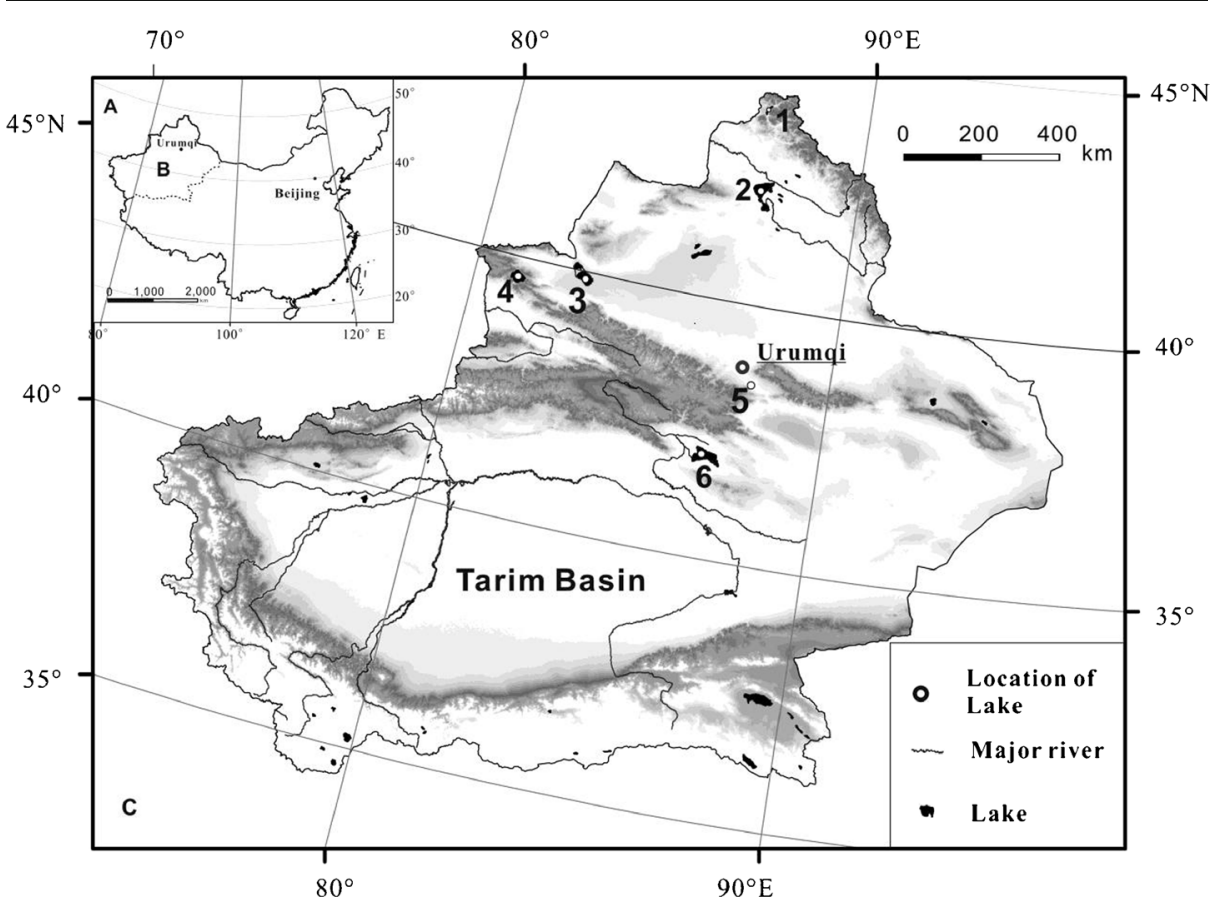

Fig. 1 Map showing the location of studied lakes in Xinjiang. Map A showing the location of Xinjiang (B) in China, map C is enlarged part B with numbered locations of studied lakes (1 Lake Kanas, 2 Lake Wulungu, 3 Lake Ebinur, 4 Lake Sailimu, 5 Lake Chaiwopu, 6 Lake Bositeng)

\section{Field and Experimental Methods}

From 2008 to 2009, the quantity and quality of water in Xinjiang lakes were investigated. A Southern Spirit boat SDE-28 echo sounder and Ling Rui S80 GPS positioning satellite system, produced by South Surveying \& Mapping Instrument Co., Ltd., were used to survey the bathymetry of the lakes. The measuring accuracy of the instrument is $0.05 \mathrm{~m}$. In the laboratory, isobath maps of selected lakes were created in ARCGIS 9.3 using data interpolation. A Multiparameter YSI 6500 water quality analyzer was used to measure total dissolved solids, salinity, $\mathrm{pH}$ and conductivity. Water samples for anions and cations were filtered using $0.45-\mu \mathrm{m}$ Whatman glass fiber filters, and then $\mathrm{HNO}_{3}$ was added to adjust the sample $\mathrm{pH}$ to $<2$ for preservation. After transport to the laboratory, $\mathrm{K}+, \mathrm{Na}^{+}, \mathrm{Ca}^{2+}$ and $\mathrm{Mg}^{2+}$ were measured by ICP-MS and Cl- and $\mathrm{SO}_{4}{ }^{2-}$ were measured by Ion Chromatography. Statistical analysis of the data was conducted using SPSS 13.0.

\section{Water Quantity and Quality of Lakes in the Past Decade}

\subsection{Water Quantity}

Oval-shaped Lake Sailimu is located in the western part of the Tianshan Mountains (Fig. 2). It is the largest mountain lake in Xinjiang. The present water elevation is $2071 \mathrm{~m}$ above sea level (asl), the maximum length is $28 \mathrm{~km}$, the greatest width is $21 \mathrm{~km}$, and the area is about $462 \mathrm{~km}^{2}$. 

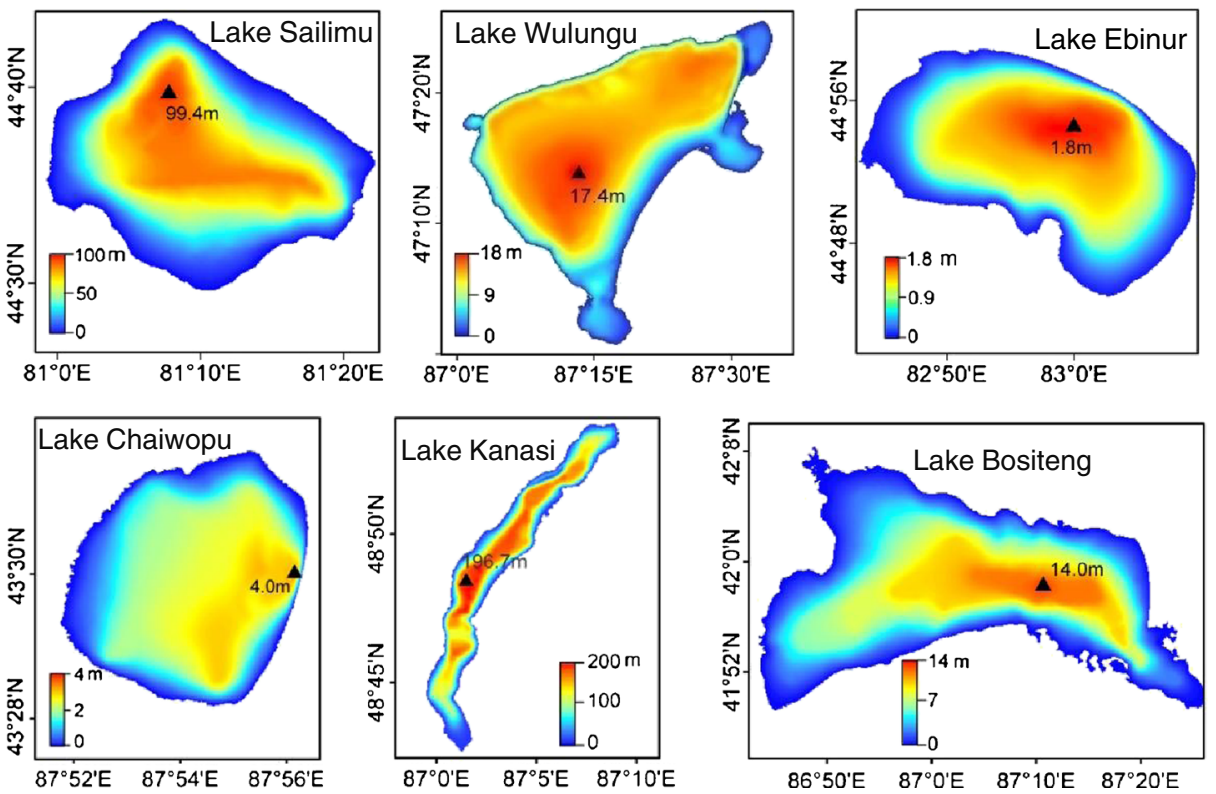

Fig. 2 Bathymetric maps of the studied lakes in the Xinjiang arid region

The maximum depth is $99 \mathrm{~m}$. Lake Kanasi is the third deepest lake in China. The water surface is at $1362 \mathrm{~m}$ asl, the greatest length is $24 \mathrm{~km}$, the maximum width is $2.6 \mathrm{~km}$, and the area is $45 \mathrm{~km}^{2}$. The maximum depth is $197 \mathrm{~m}$. The lake receives most of its hydrologic input from glacial melt water and precipitation in the Kuitun and Youyi Mountains. Lake Bositeng, the largest lake in Xinjiang, is located in the southeast part of the Yanqi Basin and is surrounded by mountains with elevations of 2,000-3,000 m. The water surface lies at $1,050 \mathrm{~m}$ asl, the greatest length is $81 \mathrm{~km}$, the greatest width is $42 \mathrm{~km}$, and the area is $1,005 \mathrm{~km}^{2}$. The maximum depth is $14 \mathrm{~m}$. Lake Chaiwopu is situated in the Chaiwopu Basin. The basin is connected with the Junggar Basin to the west, and the Baiyanggou River links it with the Turpan Basin to the southeast. The lake surface is at $1,089 \mathrm{~m}$ asl and the lake has a maximum length of $6.8 \mathrm{~km}$ and maximum width of $5.6 \mathrm{~km}$. The lake surface area is $29.6 \mathrm{~km}^{2}$. The maximum depth is $<4 \mathrm{~m}$. Lake Wulungu is located in the Fuhai Mountain Depression, Junggar-North Tianshan fold system. The lake lies at $482 \mathrm{~m}$ asl, with a maximum length and width of 45 and $26 \mathrm{~km}$, respectively. The lake area is about $859 \mathrm{~km}^{2}$. The maximum depth is $17.4 \mathrm{~m}$. Lake Ebinur is located in the lowest part of Junggar Basin, and to the northwest is Alataw Pass, which is the second Asia-Europe continental bridge and a gateway to China. The lake surface lies at $194 \mathrm{~m}$ asl and it has an area of $527 \mathrm{~km}^{2}$. The water body is $163 \mathrm{~km}$ long and it has a maximum depth of $1.8 \mathrm{~m}$.

The mountain lakes are the main freshwater storage in the Xinjiang arid region. The area of Lake Sailimu is not large, but because of its great depth, its volume is $261 \times 10^{8} \mathrm{~m}^{3}$, equal to half that of the other five lakes combined. Water stored in Lake Kanasi is $43.44 \times 10^{8} \mathrm{~m}^{3}$, somewhat smaller than Lake Bositeng, which is $59 \times 10^{8} \mathrm{~m}^{3}$. The water volumes of Lake Wulungu and Lake Ebinur are $88.93 \times 10^{8} \mathrm{~m}^{3}, 4.50 \times 10^{8} \mathrm{~m}^{3}$, respectively, and the water in Lake Chaiwopu amounts to only $0.63 \times 10^{8} \mathrm{~m}^{3}$. The area-volume variation with water depth curves for the six lakes are shown in Fig. 3. Differences between the six lakes are seen from these curves. The curves for Lake Chaiwopu and Lake Wulungu are similar. For depths of Lake Chaiwopu greater than $2 \mathrm{~m}$, and for depths of Lake Wulungu greater than $6 \mathrm{~m}$, as the 

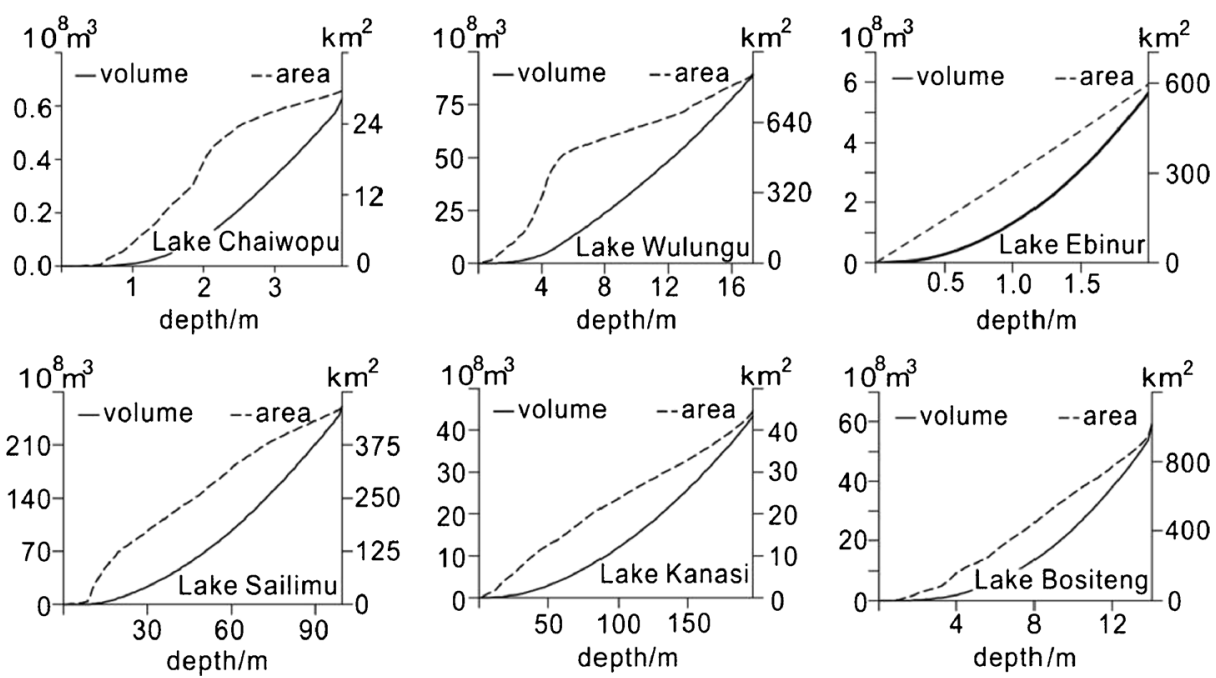

Fig. 3 Hypsographic (depth-area) curve and depth-volume curve of studied lakes in Xinjiang

water level increases the volume increases rapidly but the rate of area increase is lower. And when the water level declines, the water area and volume decrease sharply until the lake dries out. The curves for Lakes Ebinur, Sailimu and Kanasi have similar tendency in that the variation rate of area and volume with water depth is inconsistent. However, the changes of area and volume along with water depth is mainly synchronous for Lake Bositeng (Fig. 3). The divergences of the changes basically resulted from the shapes of different lake basins, and in turn, the diversities of lake responses to climate changes and human activities.

\subsection{Water Quality}

As shown in the Piper diagram of Fig. 4, the water in Lake Kanasi is bicarbonate-calcium-I type, the water in Sailimu Lake is sulfate-magnesium-II type, the waters in Lakes Wulungu, Bositeng and Chaiwopu are sulfate-sodium-II type, and the water in Lake Ebinur is chloridesodium-II type. The major cations in Lakes Wulungu, Bositeng, Chaiwopu and Ebinur were $\mathrm{K}^{+}$and $\mathrm{Na}^{+}$, which accounted for 87 and $81 \%$ of the total cations in Lake Chaiwopu and Lake Ebinur, respectively. The major anion in Lake Kanasi was $\mathrm{HCO}_{3}{ }^{-}$, and the major anion in Lake Ebinur was $\mathrm{Cl}^{-}$, which accounted for $54.1 \%$ of the total anions. The major anion of the other lakes was $\mathrm{SO}_{4}{ }^{2-}$, with highest content $(56 \%)$ in Lake Chaiwopu. The present water type of Lake Wulungu is $\mathrm{SO}_{4}{ }^{2-}$, with a concentration a little higher than that of $\mathrm{Cl}^{-}$.

Overall, ion content in Lake Kanasi was lowest, the contents of $\mathrm{Na}^{+}, \mathrm{K}^{+}, \mathrm{Ca}^{2+}, \mathrm{Mg}^{2+}, \mathrm{SO}_{4}{ }^{2-}$ and $\mathrm{Cl}^{-}$in Lake Ebinur were the highest, and the content of $\mathrm{HCO}_{3}{ }^{-}$was highest in Lakes Chaiwopu and Sailimu (Table 1). The water bodies with the highest and lowest $\mathrm{pH}$ were Lake Kanasi and Lake Sailimu, respectively. Lake Kanasi was the only freshwater lake and the salinity was $0.04 \mathrm{~g} / \mathrm{L}$, Lake Ebinur was a lagoon, and the other lakes were slightly salty lakes (Table 1).

\subsection{Water Resource Variations in the Past Decade}

Changes in lake volume and area over the last decade are different among the six lakes (Fig. 5). The areas of Lakes Bositeng, Ebinur and Chaiwopu shrunk markedly, and their water volumes 


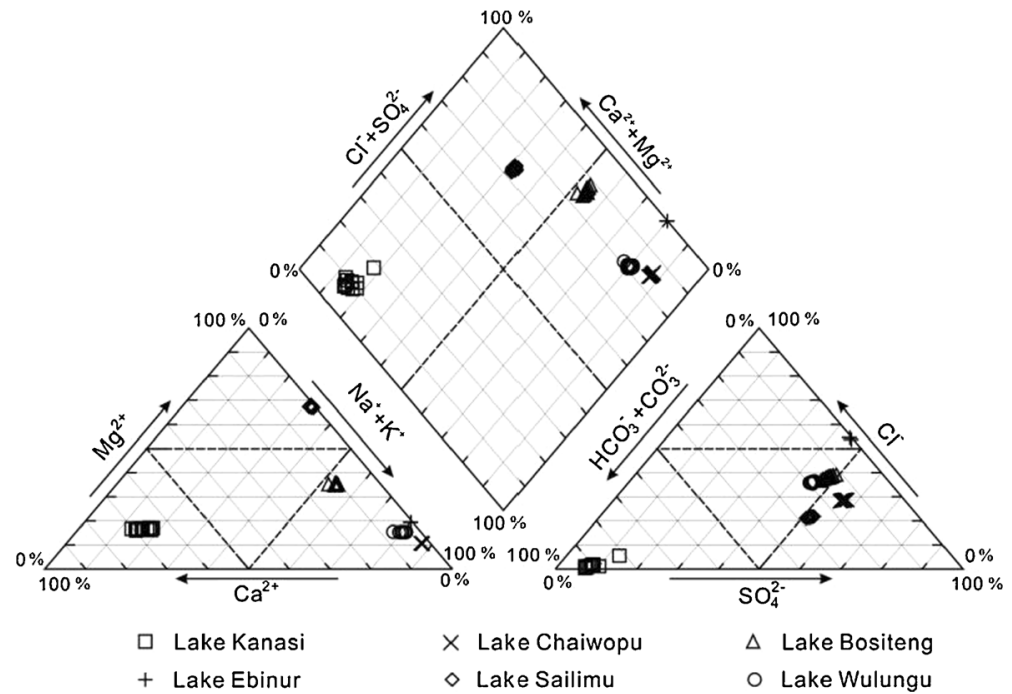

Fig. 4 A Piper diagram groups the chemical water types of the studied lakes

declined, especially in recent years. But Lake Wulungu, despite shrinking from 2006 to 2008, has expanded since then. Mountain Lakes Sailimu and Kanasi remained relatively unchanged, with Kanasi fluctuating about the mean level, whereas Sailimu displayed a low, steady increase in water level. In 2002, the area and volume of Lake Bositeng reached their highest values of $1,146 \mathrm{~km}^{2}$ and $72 \times 10^{8} \mathrm{~m}^{3}$, respectively. Values are declining thereafter, falling to the lowest points in 2009 , with an area of $928 \mathrm{~km}^{2}$ and a volume of $55 \times 10^{8} \mathrm{~m}^{3}$. The area declined by $16.7 \%$ and the volume declined by $25.3 \%$ compared to the 2002 values. After 2010, the area and volume remained relatively stable, and slightly increased. The area and volume of Lake Ebinur reached their greatest values from 2002 to 2005 , respectively, $893 \mathrm{~km}^{2}$ and $12 \times 10^{8} \mathrm{~m}^{3}$. The area and volume started sharply declining in 2006, and fell to their lowest values in 2009 , respectively, $420 \mathrm{~km}^{2}$ and $2.93 \times 10^{8} \mathrm{~m}^{3}$. In 2011, the lake area increased slightly, but the area and volume were only 52.9 and $75.5 \%$ of their respective highest values. Changes in area and volume of Lake Ebinur were the greatest of all the lakes. Before 2008, the changes in the area and volume of Lake Chaiwopu were small, fluctuating from 28.9 to $29.5 \mathrm{~km}^{2}$ and 0.56 to $0.63 \times 10^{8} \mathrm{~m}^{3}$, respectively. From 2002 to 2005 , the area and volume were both high, but started declining fast after 2008. The lake area shrunk to $26.5 \mathrm{~km}^{2}$ and the volume dropped

Table 1 Lake water quality variables

\begin{tabular}{|c|c|c|c|c|c|c|c|c|c|c|}
\hline \multirow[t]{2}{*}{ Lake name } & \multirow[t]{2}{*}{$\mathrm{pH}$} & \multirow[t]{2}{*}{ Salinity $\mathrm{g} / \mathrm{L}$} & \multicolumn{4}{|c|}{ Cation (mg/L) } & \multicolumn{4}{|c|}{ Anion (mg/L) } \\
\hline & & & $\mathrm{K}^{+}$ & $\mathrm{Na}^{+}$ & $\mathrm{Ca}^{2+}$ & $\mathrm{Mg}^{2+}$ & $\mathrm{HCO}_{3}^{-}$ & $\mathrm{CO}_{3}{ }^{2-}$ & $\mathrm{SO}_{4}^{2-}$ & $\mathrm{Cl}-$ \\
\hline Lake Kanasi & 8.17 & 0.04 & 0.68 & 0.99 & 5.28 & 0.78 & 23.07 & 0.00 & 1.66 & 0.26 \\
\hline Lake Sailimu & 9.17 & 2.75 & 31.20 & 326.25 & 7.03 & 383.64 & 554.01 & 117.85 & 1218.24 & 374.13 \\
\hline Lake Bositeng & 8.65 & 1.48 & 22.01 & 263.78 & 49.61 & 94.91 & 177.64 & 30.45 & 486.54 & 286.13 \\
\hline Lake Chaiwopu & 9.04 & 6.22 & 53.65 & 2006.5 & 41.88 & 129.67 & 871.71 & 117.20 & 3255.3 & 1216.6 \\
\hline Lake Wulungu & 8.99 & 2.34 & 72.38 & 698.13 & 35.00 & 74.02 & 329.09 & 67.72 & 893.22 & 530.96 \\
\hline Lake Ebinur & 8.40 & 102.4 & 546 & 27762 & 229 & 3215 & 279.55 & 29.52 & 32697 & 28704 \\
\hline
\end{tabular}




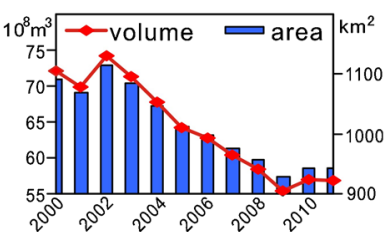

Lake Bositeng

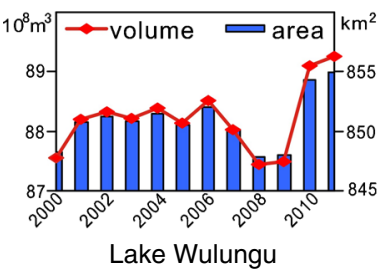

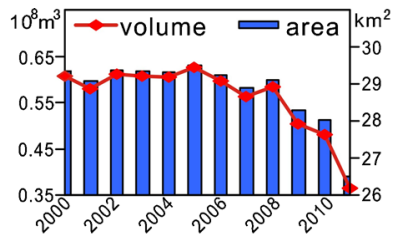

Lake Chaiwopu

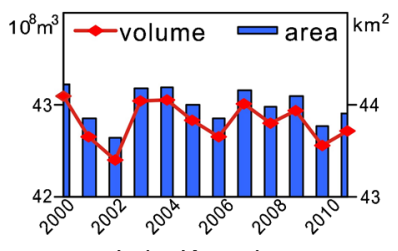

Lake Kanasi

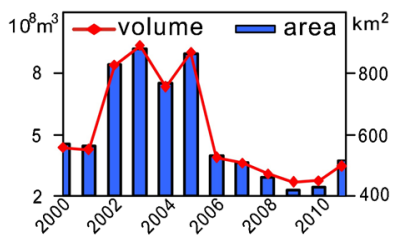

Lake Ebinur

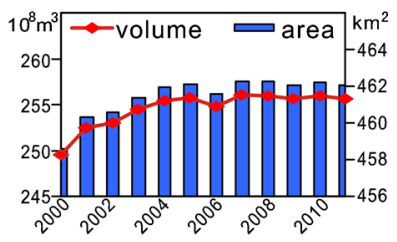

Lake Sailimu

Fig. 5 Lake volume and area changes over the past decade

sharply to $0.36 \times 10^{8} \mathrm{~m}^{3}$. Compared to the highest stage, the area declined by $10.2 \%$, and the volume declined by $41.8 \%$. The surface area and volume of Lake Wulungu fluctuated from 2000 to 2006, and dropped at a faster rate from 2006 to 2008, then rapidly increased after 2010 , and reached the highest values of the past 12 years, which were $859 \mathrm{~km}^{2}$ and $89 \times$ $10^{8} \mathrm{~m}^{3}$, respectively. The changes in area and volume of the mountain lakes were relatively small. The area and volume of Lake Sailimu from 2001 to 2011 were basically stable, fluctuating from 458.6 to $462.2 \mathrm{~km}^{2}$ and 252.5 to $259.9 \times 10^{8} \mathrm{~m}^{3}$, respectively. Lake Kanasi fluctuated in area from 43.6 to $44.2 \mathrm{~km}^{2}$, and the volume varied between 42.4 and $43.0 \times$ $10^{8} \mathrm{~m}^{3}$. The change in area of Lakes Sailimu and Kanasi was 0.4 and $1.3 \%$, respectively. And the volume changes in Lakes Sailimu and Kanasi were 1.6 and $2.5 \%$, respectively. Both lakes were thus relatively stable.

Although most of the reservoirs and lakes in China are eutrophic due to the rapid economic development with little control of the nutrient inputs (Wu et al. 2012), the nutritional status of Lakes in Xinjiang is much better (Jiang et al. 2011). Only the northwest of Lake Bositeng, among the studied lakes, occasionally reaches slight eutrophic status (Xie et al. 2011). Lakes in the Xinjiang region mainly displayed shifts in salinity and water chemistry. In the past decade, the salinity of each lake in the arid region changed along with the concentration of ions. The salinity of the water in Lake Bositeng was about $0.4 \mathrm{~g} / \mathrm{L}$ from 1958 to 1960, and started rising thereafter. From 1980 to 1991, the salinity stayed at a relatively higher level of 1.60-1.87 g/L. After 1992, the salinity began to decline and dropped to the lowest value, $1.17 \mathrm{~g} / \mathrm{L}$, in 2002 . The salinity of Lake Bositeng increased gradually from 2003, and reached $1.48 \mathrm{~g} / \mathrm{L}$ in 2008 . The salinity of Lake Wulungu was $2.72 \mathrm{~g} / \mathrm{L}$ in 1959 , and stayed at high values of $3.35-3.87 \mathrm{~g} /$ L during 1978 to 1987 . In 1988 , it declined to $2.74 \mathrm{~g} / \mathrm{L}$, and then continued declining year by year. In 2007, the salinity was reduced to $2.46 \mathrm{~g} / \mathrm{L}$ ( $\mathrm{Li}$ and Wang 2003), then decreased to $2.34 \mathrm{~g} / \mathrm{L}$ in 2008 and $2.05 \mathrm{~g} / \mathrm{L}$ in 2011. During 1988 to 2008, the hydrochemical type of Lake Wulungu changed from chloride-sodium-II type to sulphate-sodium-II type. The salinity of Lake Chaiwopu increased rapidly, from $3.62 \mathrm{~g} / \mathrm{L}$ in 1996 to $5.16 \mathrm{~g} / \mathrm{L}$ in 2006 , then to $6.22 \mathrm{~g} / \mathrm{L}$ in 2008 , reaching $7.0 \mathrm{~g} / \mathrm{L}$ in 2010 . At the end of the $1940 \mathrm{~s}$, the salinity of Lake Ebinur was about $70 \mathrm{~g} / \mathrm{L}$. From 1950 s to 1980 s, washed salt-alkali water was imported into the lake, accelerating the increase in the salinity of Lake Ebinur, and the values reached $100 \sim 115 \mathrm{~g} / \mathrm{L}$ at the end of the 1990s. In 2000, the value increased to $131 \mathrm{~g} / \mathrm{L}$. In 2002 the lake area expanded and the salinity declined to $92 \mathrm{~g} / \mathrm{L}$, and then increased to $102 \mathrm{~g} / \mathrm{L}$ in 2008 . 
The salinity of Lake Sailimu was $2.85 \mathrm{~g} / \mathrm{L}$ in $1988,2.74 \mathrm{~g} / \mathrm{L}$ in 2008 and $2.78 \mathrm{~g} / \mathrm{L}$ in 2011. Thus, salinity changes in Sailimu were small. The salinity of Lake Kanasi in 1988 was $0.05 \mathrm{~g} / \mathrm{L}$ (Wang and Dou 1998), $0.04 \mathrm{~g} / \mathrm{L}$ in 2008, $0.05 \mathrm{~g} / \mathrm{L}$ in 2009 and 2010. Overall, salinity changes across the lakes were comparable. From 2002, the salinity of Lake Bositeng increased rapidly. Salinity in Lake Wulungu fluctuated greatly and began to decline in 2008, whereas salinity values in the mountain lakes, i.e., Lakes Sailimu and Kanasi, were relatively stable.

\section{Lakes Response to Precipitation Change}

Data for precipitation and relative humidity were collected from 2000 to 2010 at six selected weather stations: (1) Fuhai in the Lake Wulungu area; (2) Dabancheng in the Lake Chaiwopu area; (3) Wenquan in the Lake Sailimu area; (4) Altai near Lake Kanasi; (5) Jinghe in the Lake Ebinur area; and (6) Yanqi in Lake Bositeng area (Fig. 6). Precipitation from 2000 to 2007 in Lake Wulungu did not display an obvious trend, but the lowest value occurred in 2008, and then precipitation began to increase. Relative humidity and precipitation were relatively stable, declined year by year from 2000 to the lowest values in 2008, and then started increasing. The lake areas and volumes changed along with it (Fig. 5). Precipitation and relative humidity in the Lake Chaiwopu area decreased from 2003, but the lake area changed slowly. After 2008, the lake area and water quantity began to change faster, especially in 2011. According to the data from Wenquan weather station, in the past decade, except for the high values around 2002, precipitation changed slightly, and correspondingly the relative humidity slightly fluctuated. The two variables show the same trends. In response to precipitation change, Lake Sailimu began to expand, but not dramatically. Except for the drought of 2008, precipitation and relative humidity fluctuated slightly in the Lake Kanasi area during the past decade, and the lake, correspondingly, did not change much. Precipitation and

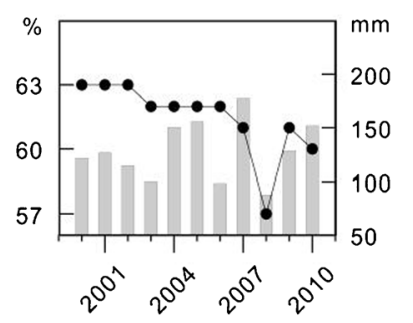

Ulungur Lake

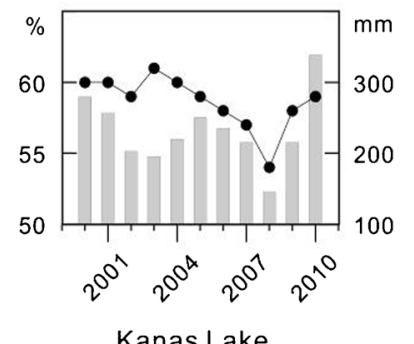

Kanas Lake

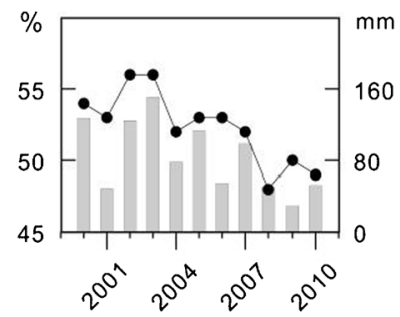

Chaiwopu Lake

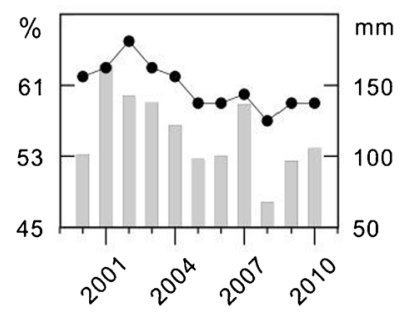

Ebinur Lake

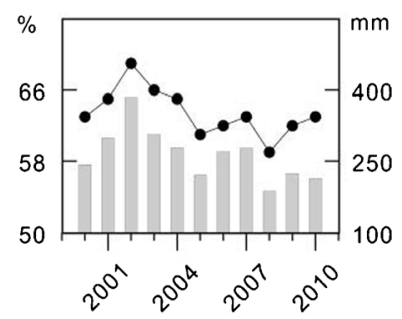

Sayram Lake

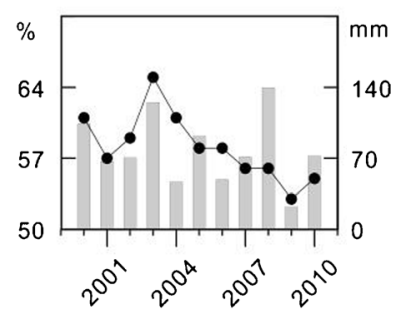

Bosten Lake Annual total precipitation $(\mathrm{mm})$

Fig. 6 Precipitation and relative humidity changes in different lake regions over the past decade 
relative humidity in the Lake Chaiwopu area fluctuated and high values appeared in 2002, but declined thereafter. Changes in precipitation were generally reflected by variations in the lake. Precipitation and relative humidity of the Lake Bositeng area decreased broadly from 2003, and the lowest values occurred in 2009. Changing trends in Lake Bositeng reflect relative shifts in precipitation.

\section{Discussion and Conclusions}

The lakes of Xinjiang region can be divided into three types based on their geographic locations: mountain lakes, oasis lakes, and tail-end lakes. In the past few decades, the mountain lakes (e.g., Lake Kanasi and Lake Sailimu) expanded to a certain degree, but the water quality and quantity slightly fluctuated. Oasis Lakes Bositeng and Chaiwopu and tail-end lakes Lake Wulungu and Lake Ebinur decreased significantly in size, but expansion of Lake Wulungu in the last 2 years was related to the large amount of winter precipitation. The lake variations generally reflected the climate changes. Because of local climate characteristics and different patterns of human activity among the lake basins, the evolutionary process has been different for each lake. Mountain Lakes Sailimu and Kanasi lie in rift basins with steep banks, and water nearly filled the basin. The lake areas have been stable and relatively insensitive to climate change. However, because there is little human influence on these lakes, any fluctuations in water level reflect regional climate changes. In the past decade, changes in Lake Sailimu clearly indicate regional climate change. On the other hand, because Lake Kanasi is an open lake, changes in lake area do not reflect periods of continuous wet weather. But because lake level was relatively stable, it indicates a lack of continuous drought in the region. Such a drought would convert the open lake to a closed system, with lake area declining continuously.

The areas of oasis Lakes Bositeng and Chaiwopu declined fairly consistently with the lower precipitation, but displayed some discrepancies in recent years. Precipitation in the Lake Bositeng area declined, accompanied by a drop in lake area. Precipitation at Lake Chaiwopu, however, did not display an obvious decrease, but the lake shrunk slowly anyway. The above phenomenon is attributed to human activities in the drainage area and basin morphology. Among the human activities in the drainage area that affected water quantity is the pumping of well water around the lake. In addition, Lake Bositeng is an open lake, and continuous shrinkage indicated a persistent drought. The water surface of closed Lake Chaiwopu was near the bottom of the basin. In the early stage of drought, the lake area did not change significantly, but the water volume did change, because the water level was low in the basin. Once water level falls considerably, the lake will shrink rapidly or even disappear. Lake Chaiwopu is now at the stage of rapid decline. Lakes Wulungu and Ebinur are tail-end lakes, with water supply coming mainly from mountain precipitation. Human activities along the river, like irrigation, could be used to meet industrial and agricultural needs. In the past decade, changes in the stage of Lake Wulungu have generally reflected climate shifts in the drainage, suggesting that the influence of water pumping is not obvious. In Lake Ebinur, however, changes are evidently influenced by human water consumption, and the lake did not respond to climate. Unlike Lake Ebinur, Lake Wulungu has expanded in the last 2 years, a shift closely related to the increase in precipitation in the Altai Mountains, especially the increase in winter precipitation. Precipitation in winter was in the form of ice and snow, and summer storms led to flooding and rapid expansion of the lake. Therefore, changes in the tail-end lakes depend on precipitation in the drainage area, but reflect the combined effects of precipitation and human activities in the plain parts of the drainage area. 
Over the past decade, changes in lake water quantity of Xinjiang lakes were accompanied by shifts in water quality. Following increases in water quantity, lake waters became fresher. Now Lake Kanasi is a freshwater lake with stable water quantity, and the salinity of Lake Sailimu remains around $2.8 \mathrm{~g} / \mathrm{L}$. The salinity of oasis Lakes Bositeng and Lake Chaiwopu, increased quickly in recent years. Salinity of tail-end Lake Wulungu fluctuates greatly whereas Lake Ebinur is a salt lake with precipitating sulphate. Currently, nutrient enrichment is not a serious problem for all the studied lakes in arid Xinjiang.

Acknowledgments We thank Zhu Xuexin for laboratory assistance. Thanks are due to Mark Brenner for his helpful comments, valuable suggestions and revision of the text, and the journal reviewers for their helpful comments and suggestions that improved the manuscript. This study was supported by National Nature Science Fund of China (U1138301; 41073010) and the National Basic Research Program of China (2012CB956100; 2010DFA9272). An initial version of this paper was presented at the 8th International Conference of the EWRA in Porto, Portugal, June 26-29, 2013.

\section{References}

Battarbee RW (1999) The importance of palaeolimnology to lake restoration. Hydrobiologia 395:149-159

Chen L, Shao Y, Zhang Q, Ren Z, Tian G (1991) Preliminary analysis of climatic change during the last 39 years in China. J Appl Meteor 2:164-173 (in Chinese with English abstract)

Ding Y, Ren G, Shi G, Gong P, Zheng X, Zhai P, Zhang D, Zhao Z, Wang S, Wang H, Luo Y, Chen L, Gao X, Dai X (2006) National Assessment Report of Climate Change (I): climate change in China and its future trend. Adv Climate Change Res (in Chinese) 2:3-8 (in Chinese with English abstract)

Gikas GD, Yiannakopoulou T, Tsihrintzis VA (2006) Water quality trends in a lagoon impacted by non-point source pollution after implementation of protective measures. Hydrobiologia 563:385-406

Guo N, Zhang J, Liang Y (2003) Climate change indicated by the recent change of inland lakes in Northwest China. J Glaciol Geocryol 25:211-214 (in Chinese with English abstract)

Jia B, Zhang Z, Ci L, Ren Y, Pan B, Zhang Z (2004) Oasis land-use dynamics and its influence on the oasis environment in Xinjiang, China. J Arid Environ 56:11-26

Jiang C, Zhu L, Hu X, Cheng J, Xie M (2011) Reasons and Control of Eutrophication in New Reservoirs, Eutrophication: causes, consequences and control. Springer, Netherlands, pp 325-340

Lai Z, Ye B (1995) Change and tendency of runoff in the northwest region of China. In: Shi Y (ed) The effect of climate change on water resources in northwest and north China. Shandong Science and Technology Press, Jinan, pp 95-119 (in Chinese)

Leng MJ, Wagner B, Boehm A, Panagiotopoulos K, Vane CH, Snelling A, Haidon C, Woodley E, Vogel H, Zanchetta G (2012) Understanding past climatic and hydrological variability in the Mediterranean from Lake Prespa sediment isotope and geochemical record over the Last Glacial cycle. Quat Sci Rev 66:123-136

Li L, Wang X (2003) The current situation of water quality in Wulungu Lake and its pollution countermeasures. Arid Environ Monit 17:102-106 (in Chinese with English abstract)

Ma L, Wu J (2009) The climate and hydrological change and environmental responses in lake sediment records of Xinjiang. J Arid Land 26:786-792 (in Chinese with English abstract)

Ma R, Yang G, Duan H, Jiang J, Wang S, Feng X, Li A, Kong F, Xue B, Wu J, Li S (2011) China's lakes at present: number, area and spatial distribution. Sci China Ser D 41:394 401

Ma L, Wu J, Abuduwaili J (2013) Climate and environmental changes over the past 150 years inferred from the sediments of Chaiwopu Lake, central Tianshan Mountains, northwest China. Int J Earth Sci 102:959-967

Micklin PP (1988) Desiccation of the Aral Sea: a water management disaster in the Soviet Union. Science 241: 1170-1176

Piao S, Ciais P, Huang Y, Shen Z, Peng S, Li J, Zhou L, Liu H, Ma Y, Ding Y (2010) The impacts of climate change on water resources and agriculture in China. Nature 467:43-51

Ren L, Wang M, Li C, Zhang W (2002) Impacts of human activity on river runoff in the northern area of China. J Hydrol 261:204-217

Sha W, Shao X, Huang M (2002) Temperature change since 1980s in China and its effect on natural area boundary. Sci China Ser D 32:317-326

Shi Y, Shen Y, Kang E, Li D, Ding Y (2007) Recent and future climate change in northwest China. Clim Chang 80:379-393 
Smol JP (1992) Paleolimnology: an important tool for effective ecosystem management. J Aquat Ecosyst Stress Recover 1:49-58

Tranvik LJ, Downing JA, Cotner JB, Loiselle SA, Striegl RG, Ballatore TJ, Dillon P, Finlay K, Fortino K, Knoll LB (2009) Lakes and reservoirs as regulators of carbon cycling and climate. Limnol Oceanogr 54:22982314

Wang S, Dou H (1998) A directory of lakes in China. Science Press, Beijing, in Chinese

Williams WD (1999) Salinisation: a major threat to water resources in the arid and semi-arid regions of the world. Lakes Reserv Res Manag 4:85-91

Wu J, Ma L (2011) Lake evolution and climatic and hydrological changes in arid zone of Xinjiang. Mar Geol Quart Geol 31:135-143 (in Chinese with English abstract)

Wu J, Zeng H, Yu H, Ma L, Xu L, Qin B (2012) Water and sediment quality in lakes along the middle and lower reaches of the Yangtze River, China. Water Resour Manag 26:3601-3618

Xie G, Zhang J, Tang X, Cai Y, Gao G (2011) Spatio-temporal heterogeneity of water quality (2010-2011) and succession patterns in Lake Bosten during the past 50 years. J Lake Sci 23:837-846 (in Chinese with English abstract)

Yuan G, Yuan L (1998) An approach to the environmental changes in Lop Nur history. Acta Geogr Sin 53:83-88 (in Chinese with English abstract)

Zhai P, Ren F, Zhang Q (1999) Detection of trends in China's precipitation extremes. Acta Meteorol Sin 57:208216 (in Chinese with English abstract) 